\title{
Vesiculobullous exanthema in a 3-month-old child with probable acute chikungunya infection
}

\section{Exantema vesiculobolhoso em criança de 3 meses com provável infecção aguda por chikungunya}

\author{
Luís Arthur Brasil Gadelha Farias ${ }^{1}$ [D, Roberto da Justa Pires Neto ${ }^{1}$ (), Robério Dias Leite ${ }^{2}$ (D) \\ 1. Departamento de Saúde Comunitária, Faculdade de Medicina, Universidade Federal do Ceará (UFC), Fortaleza, Ceará, Brasil. 2. Hospital São José de \\ Doenças Infecciosas (HSJ), Fortaleza, Ceará, Brasil.
}

\begin{abstract}
Objective: to report a rare case of a 3-month-old child with acute chikungunya infection presenting as vesiculobullous rash. Case description: herein we report a case of a 3-month-old infant which developed a diffuse erythematous rash involving the trunk and limbs within two days after sudden acute fever, and also presented striking irritability with inconsolable crying, hyporexia, cough, and coryza. Hematological and biochemical investigations were undertaken and were found to be normal. Serum samples were tested for Chikungunya revealing positive IgM. He was treated with supportive therapy, mainly with antipyretics, venous hydration and rest evolving with entirely resolution of the symptoms after four days. Comments: Chikungunya fever is a disease caused by the Chikungunya virus which can be found in endemic areas such as Brazil. Atypical manifestations can affect various systems including the skin and may be more frequent in children. The role of dermatological manifestations related to Chikungunya infection is not completely understood. The reported case is an unusual case of Chikungunya infection which highlights the importance of to know and to be aware of this manifestation in children mainly in new endemic areas such as Brazil.
\end{abstract}

Key-words: Chikungunya fever. Chikungunya vírus. Skin Diseases, Vesiculobullous. Exanthema. Communicable Diseases, Emerging.

\begin{abstract}
Resumo
Objetivo: relatar o caso raro de uma criança de 3 meses de idade com infecção aguda por chikungunya apresentando-se como erupção vesiculobolhosa. Descrição do caso: aqui relatamos o caso de uma criança de 3 meses que evoluiu com erupção eritematosa difusa envolvendo tronco e membros dois dias após febre aguda repentina, além de apresentar irritabilidade marcante com choro inconsolável, hiporexia, tosse e coriza. Investigações hematológicas e bioquímicas foram realizadas e foram normais. Amostras de soro foram testadas para Chikungunya revelando IgM positiva. Ele foi tratado com terapia de suporte, principalmente com antipiréticos, hidratação venosa e descanso evoluindo com resolução completa dos sintomas após quatro dias. Comentários: a febre Chikungunya é uma doença causada pelo vírus Chikungunya, que pode ser encontrada em áreas endêmicas como o Brasil. Manifestações atípicas podem afetar vários sistemas, incluindo a pele, e podem ser mais frequentes em crianças. 0 papel das manifestações dermatológicas relacionadas à infecção por Chikungunya não é completamente compreendido. 0 caso relatado é um caso incomum de infecção por Chikungunya, que destaca a importância de conhecer e ter consciência dessa manifestação em crianças, principalmente em novas áreas endêmicas como o Brasil.
\end{abstract}

Palavras-chave: Febre Chikungunya; Vírus Chikungunya; Dermatopatias Vesiculobolhosas; Exantema; Doenças Transmissíveis Emergentes.

\section{INTRODUCTION}

Chikungunya fever is a disease caused by the Chikungunya Virus (CHIKV) which can be found in endemic areas. Infested mosquitoes from the genus Aedes may transmit the disease ${ }^{1}$. It usually manifests as a benign and self-limited viral disease characterized by the triad: sudden fever, arthralgia/arthritis, and rash $^{2}$. Atypical manifestations have been described in the literature affecting different organs and systems such as neurological, ophthalmologic and dermatological manifestations which can be severe or debilitating ${ }^{3-6}$ Children and the elderly appear to be more affected by atypical manifestations ${ }^{7,8}$.

Herein we present a case of a 3-month-old baby diagnosed with Chikungunya fever manifested as vesiculobullous rash and conduct a brief literature review.

\section{CASE DESCRIPTION}

A 3-month-old male patient presented to our department as a result of developing a diffuse erythematous rash involving the trunk and limbs within two days after sudden acute fever (Temperature: $38,5 \circ \mathrm{C}$ ). He also presented striking irritability with inconsolable crying, hyporexia, cough, and coryza. The dermatologic examination revealed a diffuse blanchable erythematous rash resembling sunburn on his trunk, arms and lower limbs, and numerous discrete ill-defined flattened blisters containing a clear liquid, resembling heat burn (Figure $1 A-D)$. 
He had no previous history of medication before the rash onset. There was no complaint about vomits, joint swelling, blood loss, conjunctivitis or diarrhea.

Blood count was unremarkable, C-reactive protein was markedly elevated $(96 \mathrm{mg} / \mathrm{l}), \mathrm{ESR}$ was at the normal range $(15 \mathrm{~mm})$, and normal hepatic and renal functions. Cerebrospinal fluid (CSF) analysis showed a global cell count of 4 cells, glucose of $42 \mathrm{mg} /$ $\mathrm{dL}$, protein of 23,9 mg/dL, and non-reagent VDRL. Tzanck smear test of the bullous lesions was negative. Dengue investigation (nonstructural protein 1, IgM, IgG) was negative. Serum samples were also tested for Chikungunya revealing positive IgM.

Hence, the patient was diagnosed with Chikungunya fever with a vesiculobullous rash. He was treated with supportive therapy, mainly with antipyretics, venous hydration and rest. It is important to mention that breastfeeding seemed as effective as analgesics to calm the baby. After the treatment, the fever and cutaneous lesions improved within two days, and the vesiculobullous lesions resolved entirely within four days.

Figure 1(A-D): A. Flattened vesiculobullous exanthem in lower limbs. B and C. Diffuse erythematous rash in lower limbs and trunk. D. Cicatricial aspect of the bullous lesions after two days.

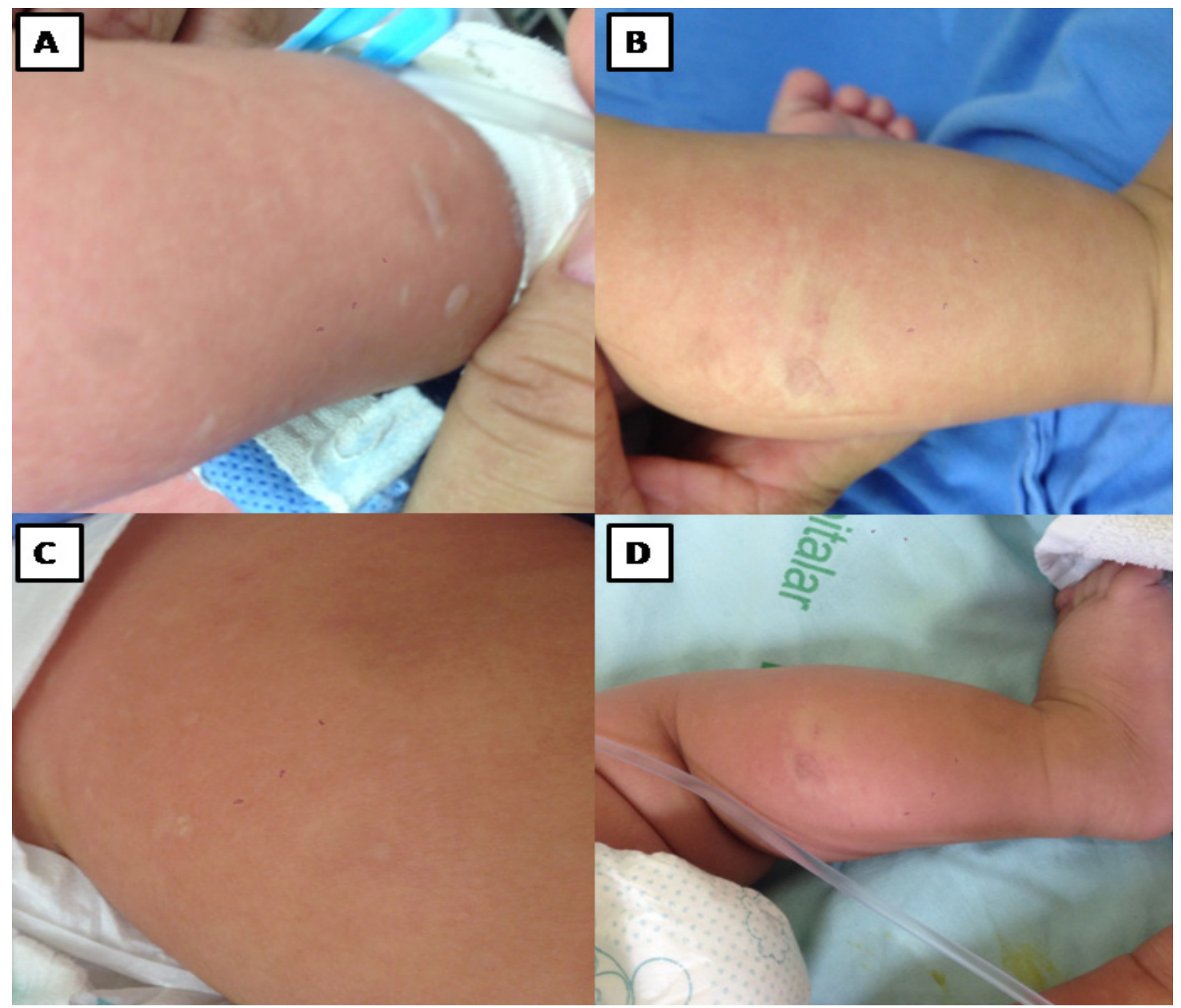

\section{DISCUSSION}

The role of dermatological manifestations in CHIKV infection is not completely understood ${ }^{9}$. Although the current incidence of vesiculobullous lesions is not known, it is believed that the virus may produce more frequent manifestations in children compared to adults. Seetharam KA et al. described 52 children diagnosed with CHIKV IgM serology in which 27 presented 
pigmentary cutaneous lesions, followed by vesiculobullous lesions (17/52) and maculopapular rash $(16 / 52)^{10}$. Other case reports showed similar lesions with complete regression varying between two and five days $s^{6,11}$.

Other skin manifestations related to the virus are hyperpigmentation; multiple aphthous-like ulcers located over the scrotum, penis, groins, perianal region, axillae, and oral mucosa; transient nasal erythema; vesiculobullous lesions; ecchymosis; subungual hemorrhage; and generalized erythema ${ }^{6}$. Patients with dermatological comorbidities such as psoriasis, leprosy, urticaria or xerosis may exacerbate and recidivate during the infection ${ }^{6,12}$. Currently, novel dermatological manifestations attributed to CHIKV have been frequently in medical literature possibly due to Chikungunya outbreaks worldwide, including Brazil ${ }^{6,13}$.

It is important to highlight the vesiculobullous manifestation in chikungunya fever because it may be related to secondary infections and dehydration, and it can increase the morbidity levels during epidemics mainly in children. Although considered a benign disease, CHIKV can also manifest as a severe disease with mild hemorrhagic manifestations and fatal cases. As presented in the case, evolution and prognosis are usually selflimited. The treatment should be based on supportive therapy and with antibiotics in case of secondary infection².

This study has limitations. First of all, this is a single case report of an uncommon manifestation. Second, although the crossreaction with Dengue and Zika virus remains low ${ }^{14}$, serum or bullous liquid RT-PCR for Chikungunya would be interesting to reinforce our diagnosis. Thus, RT-PCR was not available in our center. Third, we have not performed a biopsy for histopathological study. This decision was clinical and made considering the following reasons: (1) we already have the positive Chikungunya serology (IgM), and (2) the patient was presenting rapid improvement of the lesions following the natural history of the disease. The decision to realize a biopsy at this point could lead the patient to secondary infection and more morbidity.

The reported case is an unusual case of CHIKV infection which highlights the importance of to know and to be aware of this disease mainly in new endemic areas such as Brazil. The prompt availability of CHIKV serology associated with the clinical and epidemiological aspects was important to the correct diagnosis and management. Other differential diagnoses should be considered in the context of vesiculobullous lesions in children such as burns, staphylococcal infection, and autoimmune diseases.

\section{ACKNOWLEDGEMENTS}

We thank the patient and his parents who agreed to participate in the study and all the staff of São José Hospital of Infectious Disease.

\section{REFERENCES}

1. Ganesan VK, Duan B, \& Reid S. Chikungunya Virus: Pathophysiology, Mechanism, and Modeling. Viruses. 2017; 9(12): 368. doi: 10.3390/v9120368.

2. Cunha RV, Trinta KS. Chikungunya virus: clinical aspects and treatment - A Review. Mem Inst Oswaldo Cruz. 2017 Ago; 112(8): 523-531. doi: 10.1590/007402760170044

3. Cerny T, Schwarz M, Schwarz U, Lemant J, Gérardin P, Keller E. The Range of Neurological Complications in Chikungunya Fever. Neurocritical Care. 2017 Dec; 27(3):447-457. doi: 10.1007/s12028-017-0413-8.

4. Farias LABG, Ferragut JM, Pires Neto RJ. Encephalitis and transverse myelitis in dengue and chikungunya coinfection. Rev Soc Bras Med Trop 2018 May-Jun; 51(3):403-403. doi: 10.1590/0037-8682-0259-2017.

5. Merle H, Donnio A, Jean-Charles A, Guyomarch J, Hage R, Najioullah F, et al. Ocular manifestations of emerging arboviruses: Dengue fever, Chikungunya, Zika virus, West Nile virus, and yellow fever. J Fr Ophtalmol. 2018; 41(6): e235e243. doi: 10.1016/j.jfo.2018.05.002.

6. Beserra FLCN, Oliveira GM, Marques TMA, Farias LABG, Santos JR, Daher EF, et al. Clinical and laboratory profiles of children with severe chikungunya infection. Rev Bras Med Trop. 2019 Abr; 52:1-4. doi: http://dx.doi.org/10.1590/00378682-0232-2018.

7. Ritz N, Hufnagel M, Gérardin P. Chikungunya in Children. Pediatr Infect Dis J. 2015 Jul; 34(7): 789-91. doi: 10.1097/INF.0000000000000716.
8. Godaert L, Najioullah F, Bartholet S, Colas S, Yactayo S, Cabie A, et al. Atypical clinical presentations of acute phase chikungunya virus infection in older adults. J Am Geriatr Soc. 2017 Nov; 65(11):2510-2515. doi: 10.1111/jgs.15004.

9. Ward CE, Chapman JI. Chikungunya in Children: A Clinical Review. Pediatr Emerg Care. 2018 Jul; 34(7): 510-515. doi: 10.1097/PEC.0000000000001529.

10. Seetharam KA, Sridevi K, Vidyasagar P. Cutaneous manifestations of chikungunya fever. Indian Pediatr. 2012; 49(1): 51-53. PMID: 21992863.

11. Chandorkar N, Raj D, Kumar R, Warsi S. Fever, marked tachycardia and vesiculobullous rash in an infant with Chikungunya fever. BMJ Case Rep. 2017 Sep: bcr-2016-218687. doi: 10.1136/bcr-2016-218687.

12. Robin S, Ramful D, Zettor J, Benhamou L, Jaffar-Bandjee MC, Rivière JP, et al. Severe bullous skin lesions associated with Chikungunya virus infection in small infants. Eur J Pediatri. 2009 Jan; 169(1): 67-72. doi: 10.1007/s00431-0090986-0.

13. Singal A, Pandhi D. Isolated Nail Pigmentation Associated with Chikungunya: A Hitherto Unreported Manifestation. Skin Appendage Disord. 2018 Oct; 4(4): 312-314. doi: 10.1159/000485853.

14. Kam YH, Pok KY, Eng KE, Tan LK, Kaur S, Lee WW, et al. Sero-Prevalence and Cross-Reactivity of Chikungunya Virus Specific AntiE2EP3 Antibodies in Arbovirus-Infected Patients. PLoS Negl Trop Dis. 2015; 9(1): e3445. doi: 10.1371/journal.pntd.0003445.

How to cite this article/Como citar este artigo: 